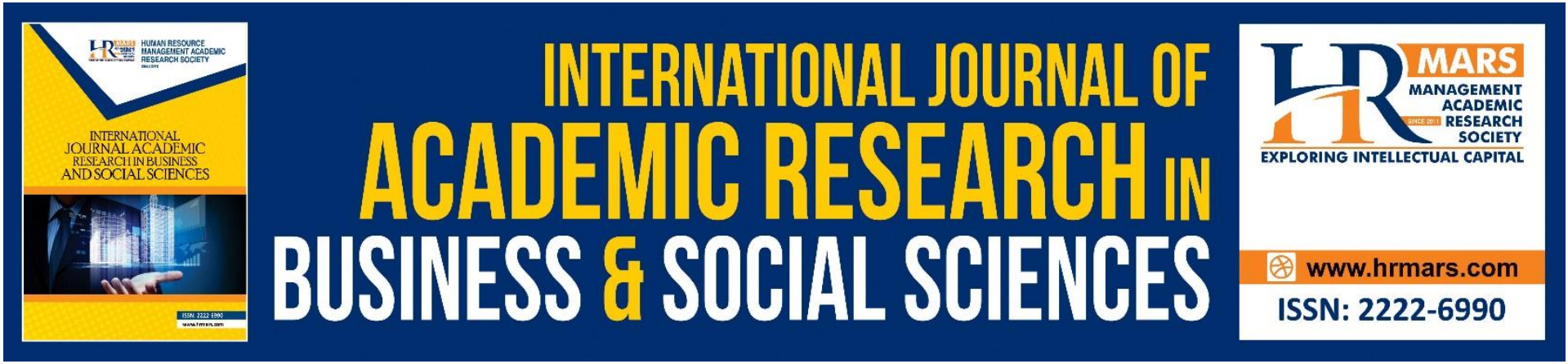

\title{
A Scoping Review on the Challenges in Implementing Universal Design on Children Public Playground
}

Lilawati Ab Wahab, Kharizam Ismail, Nor Suzila Lop, Nurul Asyikin Mohd Radzi, Mahanim Hanid

To Link this Article: http://dx.doi.org/10.6007/IJARBSS/v11-i10/11493

DOI:10.6007/IJARBSS/v11-i10/11493

Received: 15 August 2021, Revised: 20 September 2021, Accepted: 09 October 2021

Published Online: 26 October 2021

In-Text Citation: (Wahab et al., 2021)

To Cite this Article: Wahab, L. A., Ismail, K., Lop, N. S., Radzi, N. A. M., \& Hanid, M. (2021). A Scoping Review on the Challenges in Implementing Universal Design on Children Public Playground. International Journal of Academic Research in Business and Social Sciences, 11(10), 1165-1176.

Copyright: (c) 2021 The Author(s)

Published by Human Resource Management Academic Research Society (www.hrmars.com)

This article is published under the Creative Commons Attribution (CC BY 4.0) license. Anyone may reproduce, distribute, translate and create derivative works of this article (for both commercial and non-commercial purposes), subject to full attribution to the original publication and authors. The full terms of this license may be seen

at: http://creativecommons.org/licences/by/4.0/legalcode

Vol. 11, No. 10, 2021, Pg. 1165 - 1176

Full Terms \& Conditions of access and use can be found at http://hrmars.com/index.php/pages/detail/publication-ethics 


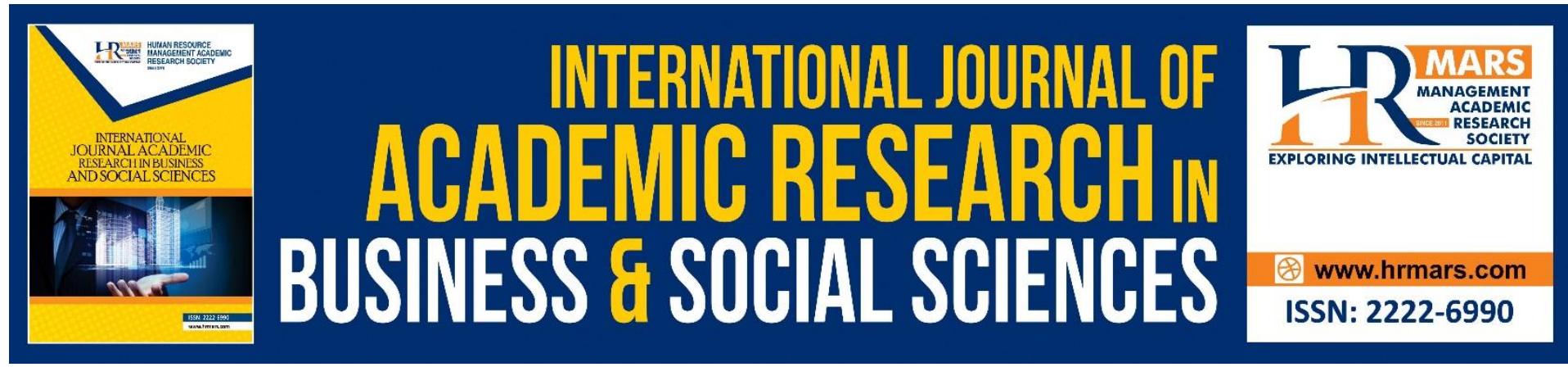

\title{
A Scoping Review on the Challenges in Implementing Universal Design on Children Public Playground
}

\author{
Lilawati Ab Wahab', Kharizam Ismail², Nor Suzila Lop³, \\ Nurul Asyikin Mohd Radzi ${ }^{4}$, Mahanim Hanid ${ }^{5}$ \\ 1,2,3 Faculty of Architecture Planning and Surveying, Universiti Teknologi MARA, Perak
} Branch, Seri Iskandar Campus, 32610 Seri Iskandar, Perak, Malaysia, ${ }^{4}$ Faculty of Architecture Planning and Surveying, Universiti Teknologi MARA, Shah Alam, Selangor, Malaysia, ${ }^{5}$ Faculty of Built Environment, Universiti Malaya, 50603, Kuala Lumpur, Malaysia.

\begin{abstract}
Playing is vital component for development of children in the sense of affective, psychomotor, cognitive, social interaction and creativity. All children including those with disabilities have the rights to experience play for their development. However, children with disabilities often face problems at public playgrounds, entertainment and amusement areas, due to the lack of ample provisions to cater to their special needs. Nowadays, many studies and debates among researchers regarding the importance of the children playground design have been conducted, however, 'inclusive' design in the children playground seems to be the exception rather than the rule. Inclusive playgrounds should be designed to provide a safe place where children of all abilities can play together, and are developmentally appropriate for children with and without disabilities. Therefore, this article is aims to describes the challenges faced in implementing Universal Design on children public playground. A scoping review method on the recent literature of inclusive play space and universal design was used to explore, locating, analysing and summarising the research findings on the nominated topic. A limited range of scoping reviews was identified, and a summary of their results were presented in two major themes. Due to limited available literature on the particular topic, the article may not able to provide a high level of rigour as systematic reviews but it generally helps to provide an overview on the research area and provide a timely summary of current evidence that can be used to encourage construction professional practitioner in incorporating Universal Design in children public playground. The outcomes of this paper can serve as a theoretical base for the development of model designed to ensure that above all, children with disabilities would have the right to play in these inclusive playgrounds safely and thus contribute to Malaysia's social sustainability and development.
\end{abstract}

Keywords: Challenges, Playground, Scoping Reviews, Universal Design.

\section{Introduction}

Children's play in the playground is often caught up as common and taken for granted childhood experience. However, the truth, not all child shares the same experience. This is 
par to a quote by Hubbard (2018), 'cities are still often designed from the perspective of the 'able-bodied', or the 'average human being, plus or minus half a standard deviation', where children with disabilities (CWD) are often left out on the playground due to disabling environment.

Besides, in the past decade, many literatures have highlighted play as a primary vehicle for children to learn and grow (Ball, 2002; Hauser and Hemke, 2009; Gleave, 2010). Play is act as central occupational to improve children's cognitive, social, and physical skills, as well as children's overall well-being and mental health. In this regard, play should be enjoyed by everyone and the right has been also recognized at the international level of under Article 31 in The United Nations Convention on the Rights of the Child (UNCRC). Indeed, UNCRC also has defines specific "at- risk' categories of child for CWDs to realise their play right. Under this international law, it is believed that every independent state is under a responsibility to take active measures to enforce these rights for all children without any discrimination, under their jurisdiction. However, despite this, the fulfilment of this play right is often thwarted as a result of both physical barriers and social exclusion exist on the playground (Moore and Lynch, 2015).

The World Health Organization (WHO) also stressed that children with disabilities and their families constantly experience barriers to the enjoyment of their basic human rights and to their inclusion in society. In addition, according to World Health Organization (WHO), there are approximately 10 per cent of the world's children and young people have sensory, intellectual or mental health disabilities. Correspondent to this many specialists has also agreed that there is a minimum working approximation of $2.5 \%$ of children between 0 and 14 years of age with self - evidence mild and severe levels of sensory, physical and intellectual impairment in one individual country. As these number of CWDs is escalating year by year, it correspondingly giving a rise the needs of CWDs and it seems plausible to argue that creating opportunities for all children to participate in play in communities is essential.

Prime consideration needs to be given to the role of the environment in permitting children to participate in play occupations. Playgrounds need to be an inclusive play space for all children. Through a rights-based approach, accessible and inclusive environments and facilities must be developed in order to enable CWDs to enjoy their rights under Article 31. It also tends to mean that the environments must be free from both physical and social barriers. Barriers are perceived in terms of accessibility, may lead CWDs to always rely on adults to the play equipment. In its worst condition, inaccessibility to playground equipment lead CWDs to feel like spectators watching others playing without the opportunity to participate. Besides, the usability of the play equipment was also one of the factors that being argued as not being adapted to the needs of the children with disabilities. Not to mentioned social interaction, but many CWDs are rarely visit public playground due to various barriers. Thus, this aspect as often remain unattained desire for CWDs.

Prior to this issue, there are also many developing countries such as United Kindgom, Australia, Hong Kong and others has established guideline for inclusive playground. However, the implementation of the inclusive playground is still low and many cities have difficulties in facilitating inclusive playgrounds (Melik \& Althuizen, 2020). This is also supported by Talay et al. (2010) stating that, despite these laws, legal arrangements and conventions, research indicates that physical environments as well as playground accessibility and usability have not been successfully implemented. This is clearly shown when Wenger et al (2020) in his study found that out of the 2319 public playgrounds in Switzerland, there are only around 40 have been built to be inclusive for all children. As for Hong Kong, in recent survey about inclusive 
play in Hong Kong, 75\% of disabled children's parents had never heard of the term 'inclusive play', and $80 \%$ of their kids have no related experience (UNICEF, 2013). Besides, Malaysian are no exception to this when UNICEF mention that in 2018 , there are only $1 \%$ of the country's playgrounds are built with the intent to accessible for children with disabilities.

Therefore, as the previous research has focused on children's experiences playing on public playgrounds and has highlighted the importance of the physical environment, which should offer high play values and affordances, as well as make a playground accessible and usable, it is found that the knowledge pertaining to the challenges of facilitating inclusive playground are still lack. Thus, this study aimed to explore the evidence of challenges in implementing inclusive playgrounds for all children.

\section{Research Method}

The study adopted a scoping review method. A scoping review has been identified as the most suitable method for conducting this study as since little research on challenges of implementing inclusive playgrounds for all children has been collected and summed up. Besides, the method of scooping review is also viewed as a key method to identify and map the available evidence from disparate areas. Although in comparison to systematic review, scooping review does not obtain the same high level of rigour, but it provide an overview of the literature through a structured methodology (Mckinstry et al., 2014). Typically, scooping review method are conducted at the initial phase of the study to establish gaps and as a foundation for intervention studies. According to Munn et al. (2018) there are five process need to be established in scooping review which are identifying research question, identifying relevant studies, study selection, charting and characterizing the data, collating, summarising and reporting the results. Besides, the author also emphasizes additional process called 'optional consultation'. Optional consultation may require when the research aim to improve the review outcome and breath.

\section{Research Question}

In this phase, aspects of the research question that identified as significant are considered to scope out the extent, range and nature of the research activity (Moore and Lynch, 2015). For this purpose, the research question that embark in this review is 'What are the challenges of implementing inclusive play environment?'

\section{Search Strategy}

The search strategy involved electronic search as a mean of conducting a broad comprehensive search. Keyword search terms such as 'challenges, inclusive play, play policy and playground' are adapted for run in four databases of PubMed, CINAHL, EBSCO and Scopus. Besides, snowballing technique are also used to make sure that there are no studies for inclusion were missed. The search was initiated in December 2020 and completed February 2021.

\section{Study Eligibility}

After the extensive search of the databases, the articles were sorted according to the eligibility criteria. It is fundamental to set criteria for inclusion and exclusion to ensure the reliability of the studies. The criteria are listed as follows:

1. The studies must be in English language and published in peer reviewed journal. 
2. The studies that focused on the challenges and the difficulties in implementing inclusive playground for both children with and without disabilities.

3. Included a focus on public playground that are intended for community use which include neighbourhood, community, or municipal playground.

4. Included a focus on the perspective of playground designers, manufactures, municipal and users in relation to implementation of inclusive play environment.

5. The studies can be quantitatively measured or qualitatively explored or mixed method.

6. There is no restriction in the publication date.

\section{Data Charting}

All papers were then uploaded to EndNote X9 (2019), Clarivate Analytics reference management software for screening and selecting process. The software independently screens the titles and abstracts using the inclusion and exclusion criteria set out by author. There is no time frame were set to ensure that all study conducted pertaining to the topic was considered. Following with the initial screening and full text article analysis as shown in Figure 1, a combine fifteen studies were excluded based on the following criteria:

1. Not concentrated on the inclusion in public playground $(n-3)$

2. Discussion not focused on barrier in implementing inclusive playground $(n-8)$

3. No full text available $(n-1)$

4. Not peer reviewed $(n-3)$

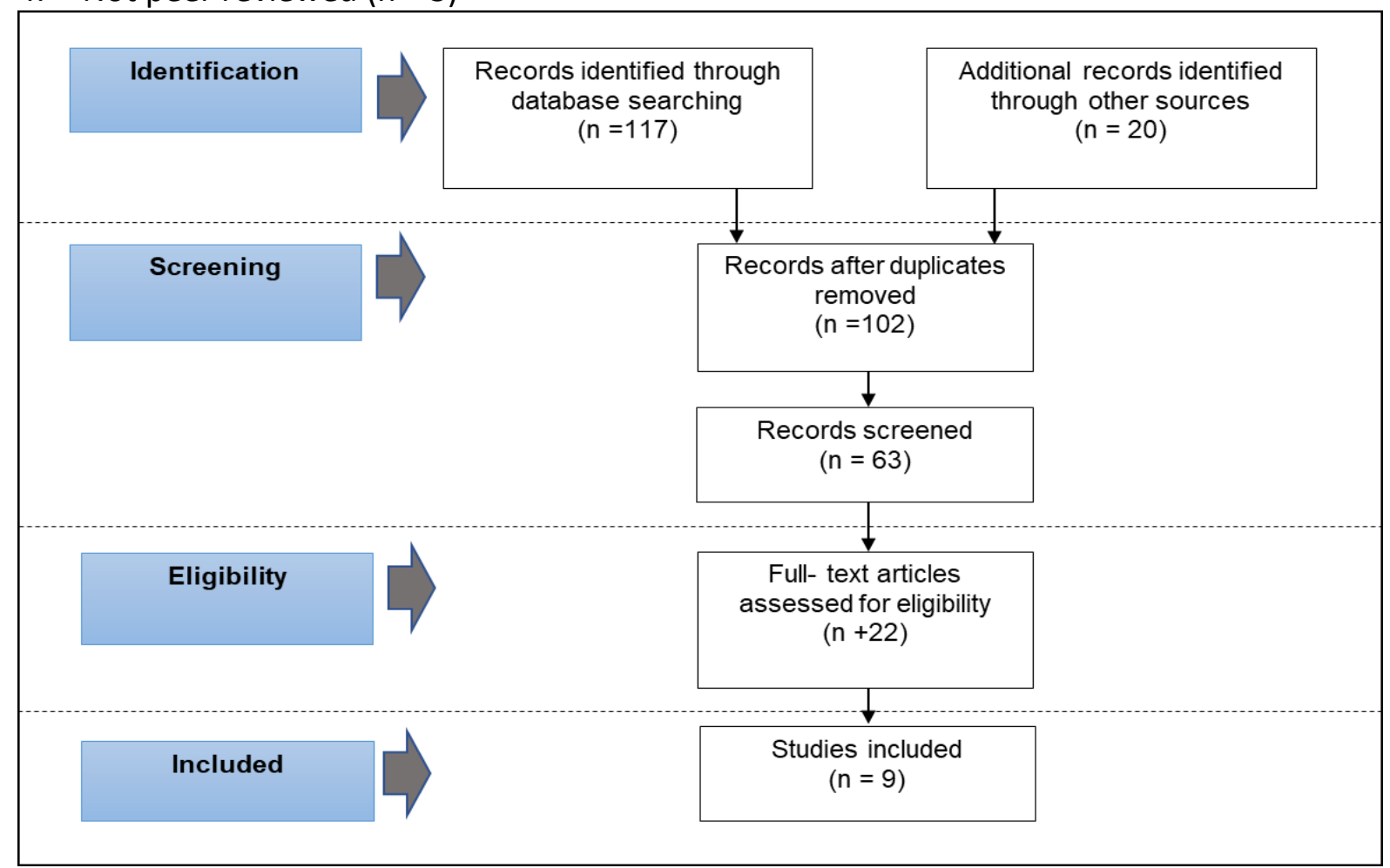

\section{Figure 1 : PRISMA Diagram}

\section{Data Analysis and Reporting}

The data obtain from the studies were extracted into the Excel spreadsheet. Item included in the data extraction: name of authors, year of studies, aim of studies, study design, participants involved and significant outcomes. 
Table 1. Previous Studies on Inclusive Playground

\begin{tabular}{|c|c|c|c|c|}
\hline Authors & Methodology & Participant & $\begin{array}{l}\text { Physical design } \\
\text { factor } \\
\text { (relating to } \\
\text { playground/ } \\
\text { environment) }\end{array}$ & Non-physical factors \\
\hline $\begin{array}{l}\text { Melik and } \\
\text { Althuizen } \\
\text { (2020) }\end{array}$ & $\begin{array}{l}\text { Quantitative } \\
\text { and } \\
\text { qualitative } \\
\text { approach has } \\
\text { been } \\
\text { adopted in } \\
\text { the study }\end{array}$ & $\begin{array}{l}\text { Online survey } \\
\text { has been } \\
\text { conducted to } \\
393 \\
\text { municipalities } \\
\text { in the } \\
\text { Netherlands }\end{array}$ & $\begin{array}{l}\text { - Adjusted } \\
\text { equipment added } \\
\text { to the existing } \\
\text { play equipment } \\
\text { was consider } \\
\text { enough to meet } \\
\text { the need of } \\
\text { children with } \\
\text { disabilities }\end{array}$ & $\begin{array}{l}\text { - Ambiguity of term. The } \\
\text { implementation of Universal } \\
\text { Design is dependent on the } \\
\text { interpretation and practices of } \\
\text { involved stakeholders. } \\
\text { - Issue of resources and finance } \\
\text { allocation } \\
\text { - Demand for inclusive } \\
\text { playground is low as the } \\
\text { number of children with } \\
\text { disabilities is limited at one } \\
\text { particular place. } \\
\text { - Lack of knowledge on what } \\
\text { adjustment necessary for an } \\
\text { inclusive playground }\end{array}$ \\
\hline $\begin{array}{l}\text { Lynch et } \\
\text { al. (2019) }\end{array}$ & $\begin{array}{l}\text { The study } \\
\text { applied } \\
\text { multiple } \\
\text { qualitative } \\
\text { approach }\end{array}$ & $\begin{array}{l}\text { Case studies } \\
\text { were } \\
\text { conducted in } \\
5 \\
\text { playgrounds } \\
\text { and } \\
\text { interviews } \\
\text { are } \\
\text { conducted } \\
\text { among } 4 \text { play } \\
\text { providers, } 12 \\
\text { children and } \\
10 \text { adults. }\end{array}$ & & $\begin{array}{l}\text { - Limited understanding of the } \\
\text { principles of universal design }\end{array}$ \\
\hline $\begin{array}{l}\text { Lynch et } \\
\text { al. (2018) }\end{array}$ & $\begin{array}{l}\text { The study } \\
\text { used a survey } \\
\text { design to } \\
\text { gather } \\
\text { information } \\
\text { from across } \\
\text { Europe on } \\
\text { the existence } \\
\text { of national } \\
\text { policies for } \\
\text { play. }\end{array}$ & $\begin{array}{l}\text { Participants } \\
\text { were eligible } \\
\text { for inclusion } \\
\text { if they were } \\
\text { members of } \\
\text { the Ludi COST } \\
\text { Action } \\
\text { network from } \\
\text { any of the } 32 \\
\text { European } \\
\text { countries. }\end{array}$ & & $\begin{array}{l}\text { - Different country's perspective } \\
\text { of disability describes in play } \\
\text { policy } \\
\text { - Lack of government investment } \\
\text { in universal design }\end{array}$ \\
\hline $\begin{array}{l}\text { Wai et al. } \\
\text { (2017) }\end{array}$ & $\begin{array}{l}\text { The study } \\
\text { applied case }\end{array}$ & $\begin{array}{l}\text { Playgrounds } \\
\text { in Hong Kong }\end{array}$ & $\begin{array}{l}\text { - Shortage of land } \\
\text { in Hong Kong. }\end{array}$ & $\begin{array}{l}\text { - Discriminative attitudes of the } \\
\text { city dwellers }\end{array}$ \\
\hline
\end{tabular}




\begin{tabular}{|l|l|l|l|l|}
\hline & $\begin{array}{l}\text { study } \\
\text { approach }\end{array}$ & $\begin{array}{l}\text { are taken as } \\
\text { case study }\end{array}$ & $\begin{array}{l}\text { Inclusive } \\
\text { playground often } \\
\text { requires larger } \\
\text { area than ordinary } \\
\text { children } \\
\text { playground }\end{array}$ & $\begin{array}{l}\text { (a) } \\
\begin{array}{l}\text { et al. } \\
(2016)\end{array}\end{array}$ \\
$\begin{array}{l}\text { Heylighen } \\
\text { approach has } \\
\text { adopted in } \\
\text { the study }\end{array}$ & $\begin{array}{l}\text { Architects } \\
\text { and built } \\
\text { environment } \\
\text { professionals }\end{array}$ & $\begin{array}{l}\text {-Concepts of inclusive design, } \\
\text { universal design and design for all } \\
\text { in were interpreted in multiple } \\
\text { ways } \\
\text {-Inclusive design need to sacrifice } \\
\text { aesthetics } \\
\text { - Need big allocation of budget } \\
\text {-Inclusive design involve more } \\
\text { complex design process }\end{array}$ \\
\hline
\end{tabular}

Table 1. Cont'd

\begin{tabular}{|c|c|c|c|c|}
\hline Authors & Methodology & Participant & $\begin{array}{l}\text { Physical design } \\
\text { factor } \\
\text { (relating to } \\
\text { playground/ } \\
\text { environment) }\end{array}$ & Non-physical factors \\
\hline $\begin{array}{l}\text { Moore } \\
\text { and } \\
\text { Lynch } \\
(2015)\end{array}$ & $\begin{array}{l}\text { Scooping } \\
\text { review } \\
\text { technique } \\
\text { has been } \\
\text { applied to the } \\
\text { research }\end{array}$ & & & $\begin{array}{l}\text {-Lack of adequate policy, } \\
\text { poorly administered system of } \\
\text { management } \\
\text { - Attitudinal barriers among } \\
\text { fund holders and policymaker } \\
\text { - Insufficient knowledge } \\
\text { pertinent to design of play for } \\
\text { children with disabilities }\end{array}$ \\
\hline $\begin{array}{l}\text { Jasinski } \\
\text { (2014) }\end{array}$ & $\begin{array}{l}\text { The study } \\
\text { adopted case } \\
\text { study } \\
\text { approach. }\end{array}$ & $\begin{array}{l}\text { The Rose Kennedy } \\
\text { Greenway Park is } \\
\text { used as case study } \\
\text { to suggest real, } \\
\text { implementable } \\
\text { recommendations } \\
\text { for the } \\
\text { incorporation of } \\
\text { universal design } \\
\text { into public parks }\end{array}$ & & $\begin{array}{l}\text { US stagnation in } \\
\text { implementing universal } \\
\text { design are due to: } \\
\text { - Network and institution } \\
\text { - Funding } \\
\text { - Not practicing inherently } \\
\text { inclusive culture like other } \\
\text { countries such as Japan and } \\
\text { United Kingdom } \\
\text { - Attitudinal barriers such as } \\
\text { language or term use in the } \\
\text { discussion of disabilities }\end{array}$ \\
\hline
\end{tabular}




\begin{tabular}{|c|c|c|c|c|}
\hline $\begin{array}{l}\text { Bringolf } \\
\text { (2010) }\end{array}$ & $\begin{array}{l}\text { The study has } \\
\text { been using in- } \\
\text { depth } \\
\text { interviews } \\
\text { and postal/online } \\
\text { survey for } \\
\text { data } \\
\text { collection }\end{array}$ & $\begin{array}{l}\text { Industry } \\
\text { participants, } \\
\text { which included } \\
\text { property } \\
\text { developers, } \\
\text { planners, } \\
\text { regulators, } \\
\text { architects, project } \\
\text { home builders, } \\
\text { building } \\
\text { designers, } \\
\text { engineers, and } \\
\text { surveyors. }\end{array}$ & & $\begin{array}{l}\text { - Misconception of universal } \\
\text { design as a term referring to } \\
\text { design for disabled people } \\
\text { - Universal Design perceived } \\
\text { increase in construction } \\
\text { cost } \\
\text { - Social attitude, disabled } \\
\text { people are considered as a } \\
\text { separate community so that } \\
\text { they need separate places } \\
\text { built specially for them }\end{array}$ \\
\hline $\begin{array}{l}\text { Al-Tal } \\
(2002)\end{array}$ & $\begin{array}{l}\text { The study } \\
\text { adopted a } \\
\text { multi- } \\
\text { method } \\
\text { qualitative } \\
\text { case study } \\
\text { approach }\end{array}$ & & $\begin{array}{l}\text {-Universal design } \\
\text { concept require } \\
\text { extensive use of } \\
\text { space } \\
\text {-Ugly in design. } \\
\text { The aesthetics of } \\
\text { adaptable design } \\
\text { are not } \\
\text { compatible with } \\
\text { mainstream } \\
\text { product standard }\end{array}$ & $\begin{array}{l}\text { - Universal design is consider } \\
\text { expensive } \\
\text { - Social problem. Non- } \\
\text { disabled people resent to } \\
\text { use structure designed for } \\
\text { people with disabilities }\end{array}$ \\
\hline
\end{tabular}

\section{Results and Discussion}

\section{Search Result}

The result from the database searches has return 117 articles and another 20 articles are sourced separately via snowballing technique. Following with removal of duplicates, the number of articles are then reduced to 102 . The process then followed with the screening of title and abstract. 22 full text articles are verified, however only 8 articles are included in the reviews as only 9 articles met the inclusion criteria required in the study. The studies published date were spanned from 2002 to 2020 with 7 studies published in the last 10 years. From the table, its clearly shows that most of studies included in the review originated from Europe or America ( $n-8 ; 88 \%)$, and there is one evidence originated from Asian country ( $n-$ $1 ; 12 \%)$. Notably, the most significant contribution are mostly made by built environments professionals such as architecture, planners and municipal (78\%). While, contribution from the playground's users were also present in the study (22\%).

The result from the review demonstrated a combination of methodologies, and mixed method approaches found across the eight studies. However, qualitative approaches were evidence as the most common method used to identify the built environment personnel's perspective on the real challenges face in implementing and integration inclusive play in children's playground. 


\section{Summary of Main Findings}

There are two core themes were identified following the charting and analysis of the data. The challenges in implementing inclusive play in children playground are divided into (1) physical design features (2) non - physical aspect.

\section{Theme 1: Physical design factors that avert/ hinder inclusion on the children's playground} Extensive use of Space

Referring to Figure 2, its shown that studies by Wai et al. (2017) and Al-Tal (2002) are both agree on the significant of use of space in creating an inclusive playground. The needs of additional space to accommodate disabilities features are often one of the top considerations for designers and municipal especially in urban areas as the land in urban area are limited. The application of Universal Design on small land could be problematic and may require tailored design solution in order to meet the need of person with disabilities especially in term of accessibility.

\section{Different Play Needs}

The challenges in implementing inclusion practically in the context of play and play equipment has been noted by Melik and Althuizen (2020). Besides, throughout the review, there was a general agreement in all articles that playground are inappropriate spaces for some children based on their age, mobility, visual and social difficulties. Lynch et al. (2019) highlight the need to provide challenges in children play but also stressed on the challenges in designing a specific solution to support children play with different abilities and progression. The process might be more difficult for children with disabilities, as creating a play equipment for children with disabilities may require more safety consideration than the ordinary children playground. Therefore, it can be said that there is no size of playground equipment that can fits all, but instead public playground can tailor the Universal Design principle in multiples perspective to possibly meet the community needs and wants.

\section{Theme 2: Non-Physical design factors that avert/hinder inclusion on the children's playground}

Ambiguity of Term

"One of the thorniest problems for everyone who works on disability issues is language" (Welch 1995). Majority of the existing research $(n-6)$ in the review has established language as one of the biggest barriers in implementing inclusive play environment. Explaining the term of inclusive design to others could be the biggest difficulties faced by its proponents. This is because in the design context language can have various distinct meaning. According to Lynch et al. (2019) in Australian building codes and planning documents, there are various language and terminology that infer to design for person with disabilities such as accessible design ; universal design ; design for all ; transgenerational design ; barrier - free design; and others. Therefore, the lack of shared understanding on the term on inclusive lead to the tendency of industry respondents to utilise the term in various way in design. The term use to define inclusive environment were used interchangeably and today is commonly use to refer a design for person with disabilities and aging people (Melik \& Althuizen, 2020). However Bringolf (2010) in his study believed that truly inclusive design would not incur any term and there is no discussion needed on the exist term as they are all built on the same foundation to position the communities in the best way. 


\section{Building Cost}

Given the confusion over the terminology of inclusive environment, the reviews highlight that there are many belief that creating an inclusive play environment will "cost a lot more" (AlTal, 2002; Jasinski, 2014; Moore \& Lynch, 2015; Bringolf, 2017). Wai et al (2017) in his study stated that many industry personnel believed that cost spend to build an inclusive play environment are sometimes outweighed the benefits. This is because in certain geographical area, the number of children with disabilities are low. Besides, some type of inclusive play equipment can hardly available in local and need to find outsource which cause higher expenditure. However, according to Bringolf (2017) the issues of cost in inclusive project are commonly occur when the adjustable or accessible feature are seen as an afterthought. For example, when the disability feature in public playground is treated as afterthought instead of being added during the design concept stage, the cost will likely to be high. Indeed, Bringold (2017) also highlighted that the construction cost to redesign the existing building is one till two percent higher than a new construction project.

\section{Attitudinal Barrier}

Attitudinal barrier are the major hinderance to a successful inclusive play environment and it can also override factor over everything. For instance, universal design is often labelled as disabled design which deemed ugly and no aesthetic value. As a result, many constructions professionals seen segregated play provision for children with disabilities is suitable to inclusion (Moore and Lynch, 2015; Bringolf, 2017; Wai et al., 2017; Lynch et al., 2019). Apart from that Bringolf (2017) mentioned that the most prevalent negative attitude is focusing on a person's disability rather than their individual abilities. Whenever a child is prevented from playing on the playground, then the entire play experience for the child is diminished. Instutional Educational Leadership (2016) argue that these kind of negative attitude can stem from ignorance, fear, misunderstanding or hatred that keep people from recognizing the rights of people with disabilities. The purpose of an inclusive playground is all about enabling every children of variety abilities to play together as a whole. It is not about overcoming legal hurdles or making expensive provision on a small community. Therefore, the awareness on children with disabilities and understanding on the development needs is require to overcome the attitudinal barrier.

\section{Lack of Knowledge on Universal Design}

Universal design coined by Ronald Maze has been widely known as a philosophical concept that introduce equality of use of space, built environment and products regardless of limitations or disabilities users might have. However, through the literature searching, it found that the knowledge and awareness of the concept of Universal Design in the realms of design is still lacking. Majority of the author $(n-8)$ agreed the present playground enviroment are not fuly adaptive or incompliance to the philosophical tenets and theoretical principles of Universal Design which continues to impedes the social engagement of the disabled. Besides, Moore and Bedford (2017) argued that the lack of awareness on Universal Design is a global issues in academic and professional practice. The need for certain adaptation requiring people with disability to gain access to everyday life and activities in public and private environments often cause stigma and sometimes seen as different. Lynch et al (2019) highlighted that implementing Universal Design into architecture, products or utilities has a number of important implications such as independence,equality, devotion, social health and associated benefits. However, academic institutions do not include Universal Design as a core 
curriculum subject in the training of architect,design and environmental planners such as town planner (Aslaksen, 1997).

\section{Conclusion}

The article has provided an overview of scoping review methodology, as well as examples of scooping reviews in the barrier of Universal Design. This scooping review has outlined that there are two core theme that move away Universal Design in the realms of design and architecture of children public playground. However, architecture and other construction professional practitioner are encouraged to consider to completing the reviews to their practice area due to the risk of study, low and limited evidences and heterogeneity in the study design.

\section{Acknowledgement}

This research was funded in part by grants from the Fundamental Research Grant Scheme (FRGS) under the Malaysian Ministry of Higher Education (MOHE). Project code: FRGS/1/2019/SSO6/UITM/02/15.

\section{Corresponding Author}

Nor Suzila Lop

Faculty of Architecture Planning and Surveying, Universiti Teknologi MARA, Perak Branch, Seri Iskandar Campus, 32610 Seri Iskandar, Perak, Malaysia.

Email: norsu993@perak.uitm.edu.my

\section{References}

Al-Tal, S. M. (2002) Integrated Universal Design: A Solution for Everyone. The Union Institute Project Demonstrating Excellence.

Aslaksen, F. (1997). Universal design: Planning and design for all. Oslo, Norway: The Norwegian State Council on Disability.

Ball, D. J. (2002) Playgrounds- Risks, Benefits and Choices. Norwich.

Bringolf, J. (2010) 'Barriers to Universal Design and what to do about them', in Australasian Housing Researchers' Conference. Australia, 1-11.

Gleave, J. (2010) 'Community play : A literature review', Play England, August, 20-43.

Hauser, A., \& Hemke, B. (2009) An Occupational Therapy Viewpoint of Accessible Playgrounds and Children with Disabilities: A Systematic Literature Review. College of St.Scholastica,Duluth.

Jasinski, L. (2014) Green \& Engaging For All : Applying Universal Design to the Rose Kennedy Greenway. Tufts University.

Leadership, I. E. (2016) Attitudinal Barriers for People with Disabilities, Leadership, Institute for Educational. Available at: http://www.ncwd-youth.info/publications/attitudinalbarriers-for-people-with-disabilities/.

Mckinstry, C., Brown, T., \& Gustafsson, L. (2014) 'Scoping reviews in occupational therapy: The what, why , and how to', Australian Occupational Therapy Journal (2014) 61,58-66, 61(1), 58-66.

Melik, R. V. A. N., \& Althuizen, N. (2020) 'Inclusive Play Policies : Disabled Children And Their Access To Dutch Playgrounds', Journal of Economic and Social Geography, 0(0), 1-14.

Moore, A., \& Lynch, H. (2015) 'Accessibility and usability of playground environments for children under 12 : A scoping review', Journal of Occupational Therapy, 22(1), 331-344. 
Moore, K., \& Bedford, J. (2017) Childhood Disability in Malaysia. Kuala Lumpur, Malaysia: UNICEF Malaysia.

Talay, L., Akpinar, N., \& Belkayali, N. (2010) 'Barriers to playground use for children with disabilities: A case from Ankara , Turkey', Journal of Agricultural Research, 5(May), 848-855.

UNICEF. (2013) 'Inclusive Play Space Guide'. Hong Kong: International Play Association, 2244.

Welch, P. (1995). Strategies for Universal Design. Boston, Massachusetts 